\title{
NEUROMUSCULAR TAPING DECOMPRESSION TECHNIQUES FAIL TO PREVENT MUSCLE DAMAGE AFTER ECCENTRIC MOVEMENT ACTIVITY
}

\author{
Muhammad Zainal Arifin, Bambang Purwanto*, Damayanti Tinduh \\ Correspondence: Universitas Airlangga, Surabaya, Indonesia \\ E-mail: bpaifo@gmail.com
}

\begin{abstract}
Eccentric activity is a type of activity facilitated by the addition of one or several muscles and often leaves the effects of pain even damage to muscle cells. The study aimed to determine the effect of the application of neuromuscular taping decompression techniques to muscle damage after eccentric movement activity. The type of research conducted is experimental research with post test only with control group design. Fourteen samples were selected from non-athlete populations at SMAN 1 Driyorejo based on consecutive sampling techniques and then divided into two groups randomly. Intervention of neuromuscular taping decompression techniques was given to the treatment group before performing eccentric movement activities. The elbow shoulderextension flexion movement by holding $9 \%$ weight in 20 seconds was chosen as the protocol of eccentric movement activity. Measuring indicators of muscle damage using a serum $\mathrm{Ck}$ muscle examination 6 hours after rest. The results of the independent t-test showed no significant difference in the variable of muscle damage ( $p>0.05$ ). It was concluded from this study that the neuromuscular taping decompression technique failed to prevent muscle damage after eccentric movement activity.
\end{abstract}

Keywords: Decompression, Eccentric Activity, Muscle Damage

\section{Introduction}

Eccentric muscle activity is often found in resistance training or in other sports activities. Eccentric activity is physical activity that involves contraction of one or several muscles that have been elongated and accompanied by an increase in muscle strength, Chen (2017): Purwanto (2014), so eccentric contractions produce greater muscle damage than concentric contractions, Suryadi (2014).

Cases of acute muscle damage reach $10-55 \%$ in overall sports injuries due to eccentric muscle contractions, Maffulli (2015). Eccentric activity has the potential to cause skeletal muscle damage and pain, Hedayatpour (2018) Due to maximum muscle lengthening in holding outside loads, Douglas (2016). Indicators of muscle damage can be seen through serum levels of creatine kinase, Baird, et al (2012). Serum creatine kinase in athletes decreases 1 day after eccentric activity and increases up to 6 days in non-athletes, Lieber (2018). Acute muscle damage accounts for $10-55 \%$ of all sports injuries due to eccentric muscle contractions, Maffulli, et al (2015). Muscle damage (muscle damage) accounted for $88 \%$ of all muscle injuries, with details: mild degree (4-7 days) $24 \%$, moderate degree (8-28 days) 51\%, severe degree (> 28 days) 13\%. Purwanto (2014). Cases

$P J K R$

http://jurnal.unimed.ac.id/2012/index.php/jpehr 
of muscle pain are delayed after eccentric activity peaks in the first $24-72$ hours and disappears after 5-7 days, Ilmi (2018).

Intervention efforts to reduce the impact of eccentric activity are proven through several studies including: Manipulation of sports massage techniques, Ilmi (2018), grape extract supplementation, Kim (2018), installation of kinesiotaping and techniques stretching, Ozmen, et al (2016) giving curcumin, Purwanto (2014), dan pemberian glutamin, Suryadi (2014). The interventions of the above studies require additional time in the recovery process. The application of the neuromuscular taping decompression technique is proposed as a recent intervention for the effectiveness of recovery time because the effect of the application has not been tested and is thought to be able to prevent muscle damage accompanying eccentric activity.

Application of neuromuscular taping decompression technique is one method of physiotherapy application that provides the effect of reducing pain, facilitating lymphatic drainage and increasing the temperature of the area attached, Blow (2012). Mala Rasni (2017) prove that the application of decompression techniques neuromuscular taping (NMT) in myofacial upper trapezius syndrome, decreases tenderness and increases the range of motion of the neck joints. Therefore, the application of NMT decompression techniques was carried out, thought to prevent muscle damage during the eccentric activity.

\section{Method}

This research is a pure experimental research with post test only with control group design. 14 samples were obtained based on the Lemeshow formula, Pratiwi (2018). The selection of research subjects was taken from non-athlete students of SMAN 1 Driyorejo based on consecutive sampling then divided into two groups randomly. Samples were obtained based on inclusion criteria, namely male sex, age $45-16$ years, nôt doing eccentricaltivity 3 days before the study, weighing $50-65 \mathrm{~kg}$, height $160-175 \mathrm{~cm}$, arm length $54-58 \mathrm{~cm}$, and has a load holding time of 20-24 seconds.

The eccentric activity protocol uses the elbow shoulder-extension flexion motion by holding a load of $9 \%$ of the sample body weight for 20 seconds. The treatment group was given the installation of a neuromuscular taping decompression technique on biceps muscle by a NMT certified physiotherapist before performing the eccentric activity protocol. Measurement of muscle damage that arises will be measured after 6 hours of rest by examination of muscle $\mathrm{Ck}$ in serum, where the normal value of male muscle Ck <190 U / 1. Data analysis using SPSS 22 application. Data analysis in sequence through descriptive analysis, normality-homogeneity, and independent t-test. 


\section{Discussion}

The number of research samples amounted to 14 people divided into 7 people each in the treatment group (K1) and control (K2). Descriptive analyzes were performed on sample criteria which included age, arm length, weight, height, and BMI.

Table 1 Analisa Deskriptif

\begin{tabular}{cccccc}
\hline Group & $\begin{array}{c}\text { Age } \\
(\mathbf{y e a r})\end{array}$ & $\begin{array}{c}\text { Sleeve } \\
\text { Length } \\
(\mathbf{C m})\end{array}$ & $\begin{array}{c}\text { Weight } \\
(\mathbf{K g})\end{array}$ & $\begin{array}{c}\text { Height } \\
(\mathbf{M})\end{array}$ & $\begin{array}{c}\mathbf{I M T} \\
\left(\mathbf{K g} / \mathbf{m}^{2}\right)\end{array}$ \\
\hline \multirow{2}{*}{ K1 (7) average \pm SD } & $15,43 \pm$ & $55,86 \pm$ & $52 \pm$ & $1,69 \pm$ & $18,21 \pm$ \\
& 0,54 & 1,46 & 5,32 & 0.04 & 1,36 \\
$\mathbf{K 2}(7)$ average \pm SD & $15,71 \pm$ & $55,71 \pm$ & $53,86 \pm$ & $1,66 \pm$ & $19,45 \pm$ \\
$\mathbf{P}$ & 0,49 & 1,11 & 5,87 & 0,11 & 2,17 \\
& $0,351^{*}$ & $0,223^{*}$ & $0,790^{*}$ & $0,41^{*}$ & $0,239^{*}$ \\
\hline
\end{tabular}

Information:

*: Homogeneous distribution

Based on table 1, it can be concluded that the sample has homogeneous criteria ( $p>0.05)$. Furthermore, normality and homogeneity were tested on the variable muscle damage

Table 2. Uji Normalitas and Homogenitas

\begin{tabular}{|c|c|c|c|c|}
\hline Group & $\mathbf{N}$ & $\begin{array}{c}\text { CK Mucle } \\
\text { Mean } \pm \text { SD }\end{array}$ & $\begin{array}{c}\text { p - Uji } \\
\text { Normalitas }\end{array}$ & $\begin{array}{c}\text { p - Uji } \\
\text { Homogenitas }\end{array}$ \\
\hline $\begin{array}{l}\text { K1 } \\
\text { K2 }\end{array}$ & 7 & $\begin{array}{l}375,71 \pm 117,656 \\
417,71 \pm 49,574\end{array}$ & $\begin{array}{l}0,223 \\
0,810\end{array}$ & 0,130 \\
\hline
\end{tabular}

Based on table 2, it can be concluded that the muscle damage data in each group is normally distributed ( $p>0.05$ ) and homogeneous ( $p>0.05$ ). Next, an independent t-test is performed to see the effect of the neuromuscular taping decompression technique.

Table 3. Uji independent t-test

\begin{tabular}{rrr}
\hline & Sig.(2-tailed) \\
\hline Serum creatine kinase muscle & $\mathrm{K} 1-\mathrm{K} 2$ &, 401
\end{tabular}

Based on table 3 , it can be concluded that there were no significant differences between the treatment and control groups $(p=0.401>0.05)$, so it was concluded that the application of neuromuscular taping decompression techniques failed to prevent muscle damage during eccentric movement activities in the study subjects.

The aim of this study was to determine the acute effect of the application of the neuromuscular taping decompression technique on muscle damage during eccentric activity. The elbow shoulder-extension flexion movement by holding 9\% body weight for 20 seconds was chosen as the protocol for eccentric 
movement activity. Samples according to inclusion criteria and homogeneous distribution. The application of the neuromuscular taping decompression technique was given to the treatment group before the eccentric activity test protocol was carried out as a research intervention. Measurable creatine kinase in serum 6 hours after rest.

Biomechanically, the elbow shoulder-extension flexion movement is a triple lever system, Okuno (2014), so that the muscle force that is released is a product of arm length and weight. The average weight of the sample is 52-53, then the load is obtained $4-5 \mathrm{~kg}$ (rounding). The average length of the sample arm is $55 \mathrm{~cm}$. so the force exerted a very large muscle that is $220-275$ Newton in the short head of biceps muscle as a muscle that has an elongated contraction. In addition, the elbow shoulder-extension flexion motion by holding the load is an isotonic muscle contraction with an eccentric type of work so that muscle lengthening occurs with a constant tension for 20 seconds. Isotonic muscle contractions with eccentric type of work are contractions of muscles with a constant load from the beginning to the end of the movement with both ends / attachments of muscles (origo and insertion) moving away from each other in terms of more elongated muscles, Suryadi (2014). Eccentric muscle movements (elongation of muscles) occur as braking or force of resistance to concentric movements in many movements to protect joint structures from damage or injury, Bubbico (2010). Mean serum CK muscle K2> K1 after 6 hours of rest (417.71> 375.71). This indicates that both groups experienced muscle damage (normal muscle CK <190 U / 1.) And NMT application of decompression did not provide a significant difference in effect $(\mathrm{p}=0.401)$.

One indicator of muscle damage after eccentric activity is increased pain intensity, decreased muscle strength, and increased levels of muscle CK, Castro (2011); Ilmi (2018). Increased pain is the body's defense mechanism, arising when there is damaged tissue land this will cause the individual to react by moving the pain stimulus, Guyton (2011). Decreased muscle strength occurs 1 - 48 hours after eccentric activity, Suryadi (2014). Increased levels of CK occur due to prolongation of excess muscle sarcomeres and release of calcium ion substance, Effendi (2009); Jackman (2011). Serum CK decreased by 1 day after exercising and increased to 6 days in non-athletes, Lieber (2018).

Neuromuscular taping is an application technique on the skin using elastic adhesive tape that is hippoallergenic with the aim of providing a local therapeutic effect. Specific application of elastic bands that form wrinkles by lifting the skin gives the effect of reducing pain, lymphatic drainage facilities, increasing the temperature in the area of the body that is mounted, increasing the functional ability of muscles, stimulating the nervous system, and helping the healing process, Blow (2012).

The application of neuromuscular taping to the decompression technique provides an eccentric effect on the muscles, so that when combined with traction 
on the skin it will increase muscle length, fascia tissue, and skin, Blow (2012). According to, Endaryanto's research (2018), NMT decompression increases gastrocnemius muscle strength. Based on the results of the independent $t$ test analysis, NMT decompression applications installed during eccentric activity did not give a difference in effect on muscle CK between $\mathrm{K} 1$ and $\mathrm{K} 2(\mathrm{p}=0.401)$ after 6 hours of eccentric activity. How ever the mean CK of K1 muscle is lower than $\mathrm{K} 2$, meaning that the application of NMT decompression gives a different effect on muscle damage in $\mathrm{K} 1$ and $\mathrm{K} 2$.

The application of NMT decompression to improve sports performance especially to prevent muscle damage after eccentric activity has never been done. The majority of research with NMT application of decompression is used as a healing therapy for pain originating from a disease. Like Rasni and Hamami research (2017), the application of NMT decompression provides a reduction in tenderness in the Upper Trapezius Myofacial Syndrome and low back pain. The study showed that the application of NMT decompression was used after pain in the body.

Measurement of serum muscle CK is only performed 6 hours of rest after eccentric movement activity, so the effect of NMT decompression applications in this study is less than optimal, because the effects of the application are only used for 6 hours, whereas the effects of NMT application can be used for up to 4 days, Mazzarini (2011). Therefore, the alleged difference in effect of application experiments is not yet optimal.

Taping applications cannot increase muscle strength, Csapo (2014); Gomez (2013); Keet (2009); Zhang (2015), so the expected increase in power when muscle lengthening is not facilitated. In addition, the elbow shoulderextension flexion movement is an eccentric activity with high intensity because the load performed is $9 \%$ body weight, Pora (2014).

Based on the research and theory described above, researchers are of the opinion that the acute influence of the application of neuromuscular taping decompression techniques cannot prevent muscle damage after eccentric movement activity.

\section{Conclusion}

The application of the neuromuscular taping decompression technique fails to prevent muscle damage after eccentric movement activity.

\section{References}

Baird, MF, Scott M. Graham, Julien S. Baker, and Gordon F. Bickerstaff, 2012. Creatine-Kinase- and Exercise-Related Muscle Damage Implications for Muscle Performance and Recovery. Journal of nutrition and metabolism. Volume: -, Edisi: -: - 
Blow, D., 2012. Neuromuscular Taping from Theory to Practice. Milan: Arti Grafiche Colombo-Gessate.

Bubbico A and Kravitz L, 2010. Eccentric Exercise: A Comprhensive Review of A Distinctive Training Method. IDEA Fitness Journal. Volume: 7, Edisi: : 50-59.

Castro AP, Vianna JM, Damasceno VO, Matos DG, Filho ML, 2011. Muscle Recovery After Session of Resistance Training Monitored Through Serum Creatine Kinase. Journal exercise physiology. Volume: 14, Edisi: -: 38-45.

Chen, et.al, 2017. Low intensity elbow flexion eccentric contractions attenuate maximal eccentric exercise induced muscle damage of the contralateral arm. Journal of Science and Medicine in Sport. Volume: -, Edisi: -: -.

Csapo R, Alegre LM, 2014. Effects of Kinesio taping on skeletal muscle strength-A meta-analysis of current evidence. Journal of Science and Medicine in Sport. JSAMS. Volume: 18, Edisi: 4: 450-456. http://dx.doi.org/10.1016/j.jsams.2014.06.014.

Douglas, Jamie, et al, 2016. Eccentric Exercise: Physiological Characteristics and Acute Responses. Journal of Sport Medicine. Volume: -, Edisi: -: -. DOI: 10.1007/s40279-016-0624-8.

Effendi C, Santoso KP, Purwanto B, 2009. Buku Ajar Faal Sel, Cair Tubuh, Saraf Tepi, dan Otot. Surabaya: Departemen Ilmu Faal- Universitas Airlangga.

Endaryanto, AH, 2018. Pengaruh Nuromuscular Taping Terhadap Kekuatan, Fleksiibilitas Otot Dan Waktu Tempuh Sprinter 100 M. Surabaya: TesisUNAIR.

Gómez-Soriano J, et al., 2013. The effects of Kinesio taping on muscle tone in healthy subjects: A double-blind, placebo-controlled crossover trial, Manual Therapy. Volume: -, Edisi: -: http://dx.doi.org/10.1016/j.math.2013.09.002.

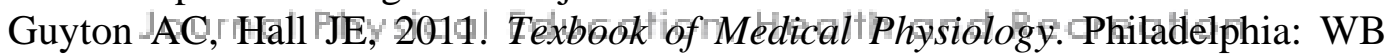
Saunders Company.

Hammami, YN, 2017. Perbedaan Pengaruh Pemberian Kinesio Taping Dan Neuromuscular Taping Terhadap Penurunan Nyeri Punggung Bawah. UMS: NAskah Publikasi.

Ilmi, Mochamad Azhar, 2018. Pengaruh Manipulasi Sport Massage Terhadap Creatine Kinase Serum, Range of Motion (Rom), Dan Intensitas Nyeri Setelah Aktivitas Eksentrik. Surabaya: Thesis-UNAIR.

Kim, Joo Young Dan Wi Young-Soo, 2018. Effects of Acute Grape Seed Extract Supplementation On Muscle Damage After Eccentric Exercise. Journal of Exercise Science \& Fitness. Volume: -, Edisi: -: -.

Jackman SR, 2011. Whole Body and Muscle Response to Protein and Branced Chain Amino Acid Feeding Following Intense Eercise. Inggris: Eercise Metabolism Research Group School of Sport and Eercise Sciences. University of Birmingham.

PJKR

http://jurnal.unimed.ac.id/2012/index.php/jpehr 
Keet, Janet H.L., Janine Gray, Yolande Harley, Mike I. Lambert, 2009. The effect of medial patellar taping on pain, strength and neuromuscular recruitment in subjects with and without patellofemoral pain. Journal of Physiotherapy. Volume: 93, Edisi: -: 45-52.

Lieber, Richard L, 2018. Biomechanical response of skeletal muscle to eccentric contractions. Journal of Sport and Health Science. Volume: -, Edisi: -: -. https://doi.org/10.1016/j.jshs.2018.06.005

Maffulli, Nicola, et al, 2015. Muscle Injuries: A Brief Guide to Classification and Management. Translational Medicine @UniSa. Volume: -, Edisi: -: -.

Mazzarini, M, 2011. The Use of NMT Concept Neuromuscular Taping for Treatment of Low Back Pain. USA: NMT Institute Journal Naeuromuscular Taping Institute Atlanta Georgia.

Okuno, Emeric dan Luciano Fratin, 2014. Biomechanics of the Human Body. New York: Springer.

Ozmen T, Yagmur Gunes G, Dogan H, Ucar I, Willems M, 2016. The Effect of Kinesio Taping Versus Stretching Techniques On Muscle Soreness, And Flexibility During Recovery from Nordic Hamstring Exercise. Journal of Bodywork \& Movement Therapies. Volume: -, Edisi: -

Pora, Yosefina D, 2014. Pengaruh Latihan Eksentrik Sesaat (Lari Downhill) pada Sudut Deklinasi $-5^{\circ},-10^{\circ}$ dan $-15^{\circ}$ terhadap Penurunan Kadar GLUT -4 pada Otot Gastrocnemius Mencit (Mus Musculus). Surabaya: ThesisUnair.

Purwanto, Bambang, 2014. Mekanisme Kerja Curcumin Dalam Mencegah Kerusakan Otot Rangka Mencit Yang Melakukan Aktivitas Eksentrik Sesaat. Surabaya: Disertasi-UNAIR.

Pratiwi, Wahyu N, 2018. Pengaruh Senam Persadia I terhadap Kadar IL-6 dan Kolesterol Total Darah Pada Ibu PKK Lidah Wetan Surabaya. Surabaya: Thesis-Unair.ysical Education. Health and Recreation

Rasni, Mala, 2017. Pengaruh Aplikasi Neuromuscular Taping (Nmt) Pada Sindroma Miofasial Upper Trapezius Terhadap Penurunan Nyeri Tekan Dan Peningkatan Lingkup Gerak Sendi Leher. UMS: Naskah Publikasi.

Suryadi, Agus, 2014. Efek Pemberian Glutamin Terhadap Kekuatan Otot dan Rentang Gerak Sendi (Range of Motion) Setelah Aktivitas Eksentrik. Surabaya: Thesis-UNAIR.

Zhang S, et al, 2015. Acute effects of Kinesio taping on muscle strength and fatigue in the forearm of tennis players. Journal of Science and Medicine Sport. Volume: -, Edisi: -: -.http://dx.doi.org/10.1016/j.jsams.2015.07.012.

PJKR

http://jurnal.unimed.ac.id/2012/index.php/jpehr 